\title{
Normalograptus kufraensis, a new species of graptolite from the western margin of the Kufra Basin, Libya
}

\author{
ALEX PAGE* $\ddagger \dagger$, GUIDO MEINHOLD§ , DANIEL P. LE HERON\| \& \\ MOHAMED ELGADRY\# \\ * Department of Earth Sciences, University of Cambridge, Downing Street, Cambridge CB2 3EQ, UK \\ $\ddagger$ Current address: Dauntsey’s School, West Lavington, Wiltshire SN10 4EP, UK \\ $\S$ CASP, University of Cambridge, West Building, 181A Huntingdon Road, Cambridge CB3 0DH, UK \\ qDepartment of Sedimentology \& Environmental Geology, Geoscience Centre, University of Göttingen, \\ Goldschmidtstraße 3, 37077 Göttingen, Germany \\ ||Department of Earth Sciences, Queen's Building, Royal Holloway University of London, \\ Egham, TW200EX, UK \\ \#Libyan Petroleum Institute, Gergarish Road, P. O. BOX 6431, Tripoli, Libya
}

(Received 20 February 2012; accepted 6 September 2012; first published online 11 February 2013)

\begin{abstract}
Normalograptus kufraensis sp. nov. occurs as monospecific assemblages in the Tanezzuft Formation at the western margin of the Kufra Basin (Jabal Eghei), southern Libya. These graptolites have parallel-sided rhabdosomes with long, straight virgellae, climacograptid thecae and a full straight median septum. $N$. kufraensis is intermediate between Ordovician graptolites from the $N$. angustus (Perner) lineage and the younger sister species $N$. ajjeri (Legrand) and N. arrikini Legrand. $N$. kufraensis differs from these taxa as follows: it is broader than $N$. angustus; it has greater thecal spacing than $N$. ajjeri or $N$. arrikini. A table comparing measurements of $N$. kufraensis with 44 other Normalograptus taxa differentiates it from other members of this morphologically conservative group. Even though $N$. angustus and $N$. ajjeri are very long-ranging graptolites, a stratophenetic approach suggests that the specimens from Jabal Eghei may be of late Hirnantian or younger age. The faunal composition and preservation suggests these graptolites occupied the 'cratonic invader' biotope. The stratigraphic succession records deglacial flooding and fluctuating of redox in the Tanezzuft Formation, with the graptolites indicating a short-lived interval of anoxia.
\end{abstract}

Keywords: biostratigraphy, Silurian, Gondwana, Africa, evolution, glaciation, Palaeozoic.

\section{Introduction}

The late Ordovician and early Silurian graptolite faunas from the northern margin of Gondwana are crucial to determining the age and event stratigraphy of the region's petroleum rich rocks (P. Legrand, unpub. Ph.D. thesis, Univ. Michel de Montaigne-Bordeaux III, 1999; Legrand, 2003; Armstrong et al. 2005; Loydell, 2007). This is particularly the case as limestone-hosted shelly faunas are generally absent (Walker, Wilkinson \& Ivany, 2002; cf. Fortey \& Cocks, 2005; Cherns \& Wheeley, 2007), and most localities yield low-diversity graptoloid faunas comprising long-lived cosmopolitan forms and short-lived endemic taxa (Underwood, Deynoux \& Ghienne, 1998; P. Legrand, unpub. Ph.D. thesis, Univ. Michel de Montaigne-Bordeaux III, 1999; Zalasiewicz, 2001; Legrand, 2003). However, recent detailed studies of more complete successions from the Hirnantian and Llandovery of northern Gondwana (e.g. Underwood, Deynoux \& Ghienne, 1998; Storch \& Massa, 2003; Loydell, 2007, 2012b; Zalasiewicz et al. 2007) have shown the total regional graptolite fauna to be comparable to those of peri-Gondwanan Europe, affording relatively detailed biostratigraphic

$\dagger$ Author for correspondence: alexpageesq@gmail.com correlation for the very latest Ordovician and early Silurian of northern Gondwana (Loydell, 2007, 2012a).

Nonetheless, in the late Ordovician of North Africa the picture is more complicated: though the occurrence of an endemic graptoloid fauna has been documented and a regional stratigraphy erected (see P. Legrand, unpub. Ph.D. thesis, Univ. Michel de MontaigneBordeaux III, 1999; Legrand, 2003), the precise age of the local zonation remains uncertain. This may be in part owing to a glaciotectonic unconformity that persists through much of Africa and Arabia of Caradoc (viz. Sandbian - mid Katian) to Hirnantian age (Destombes, Holland \& Willefert, 1985; P. Legrand, unpub. Ph.D. thesis, Univ. Michel de MontaigneBordeaux III, 1999; Legrand, 2000, 2003; Sutcliffe et al. 2001; Ghienne et al. 2007; A. A. Page, unpub. Ph.D. thesis, Univ. Leicester, 2007; Le Heron \& Craig, 2008). This unconformity has recently been recognized in the northern and eastern flanks of the Kufra Basin (Le Heron \& Howard, 2010; Le Heron et al. 2010). Legrand (2003, p. 19) noted that understanding the regional stratigraphy of the "Algerian Sahara and adjacent regions ... [is hindered by lack of constraint concerning] (a) epeirogenic movements and erosion; (b) the nature of the glacial, periglacial, deltaic and fluvial sediments; (c) one glaciation, multiple 


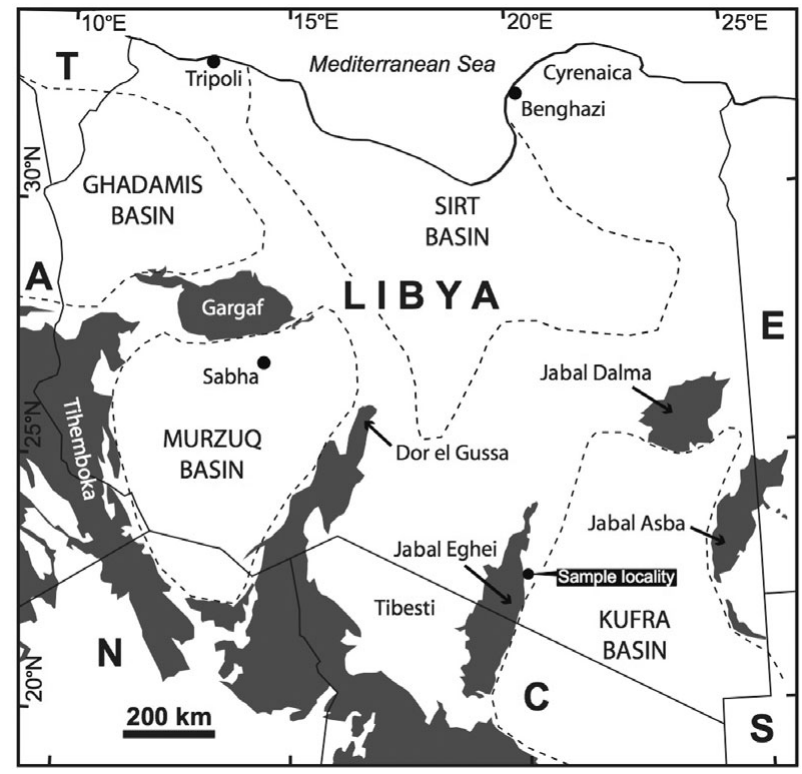

Figure 1. Map of Libya showing surface outcrops with Palaeozoic rocks (dark grey colour). The sampling locality of graptolite-bearing specimens is indicated.

glaciations or only a polyphase glaciation; (d) the varying importance of unconformities; (e) the age of the uppermost Ordovician formations, i.e. whether they are uppermost Ashgillian or upper Caradocian-upper Ashgillian and the precise age of the last Hirnantia fauna'. Nevertheless, if Ordovician or early Silurian graptolites can be precisely identified, regional if not global correlation is possible.

In this study, we describe Normalograptus $k u$ fraensis, a new species of normalograptid graptolite from a thin marker horizon in the Lower Palaeozoic Jabal Eghei succession of the western Kufra Basin in southern Libya. Though graptolites from the Murzuq Basin in NW Libya have been recently documented (Loydell, 2012b), the graptolites of the Kufra Basin are poorly known. These specimens, uncovered in CASP fieldwork in November-December 2008, are the first graptolites from Kufra Basin outcrops, and comprise well-preserved specimens that may be of key importance for understanding regional stratigraphy, particularly the timings of glaciation and of the onset of anoxia.

\section{Geological setting}

Marine and continental Palaeozoic and Mesozoic sandstones and shales of up to $2600 \mathrm{~m}$ in thickness fill the Kufra Basin in SE Libya (e.g. Bellini et al. 1991). This paper describes material recovered from Jabal Eghei, an outcrop belt located at the western margin of the Kufra Basin (Fig. 1). Sections were studied about $100 \mathrm{~km}$ north of the Libya-Chad border. The graptolite-bearing bed belongs to the Tanezzuft Formation, which is described below as well as in Le Heron et al. (in press).
In Jabal Eghei, the Tanezzuft Formation displays distinct sedimentological characteristics not encountered elsewhere in the Kufra Basin (Fig. 2). These include, from the base up, (1) a calcareous, bryozoa-bearing sandstone immediately at the basal contact of the formation to the underlying Mamuniyat Formation, (2) Planolites-bearing sandstones, (3) a soft-sediment striated surface of putative glacial origin (Le Heron et al. 2005), (4) an interval with calcareous, pebblesized clasts (?dropstones) below and above this surface, (5) a second bioturbated horizon, and further up a shale succession with (6) an impressive (20 cm thick) marker bed containing well-preserved graptolites. The Tanezzuft Formation has a maximum thickness of about $50 \mathrm{~m}$ owing to post-depositional erosion.

Note that macrofossils are generally rare in the Lower Palaeozoic succession of southern Libya, and palynomorphs have mostly been destroyed at outcrop by intensive surface weathering. This hampers precise dating and correlation with successions elsewhere in Libya and North Africa. More common are trace fossils (e.g. Lüning et al. 1999; Seilacher et al. 2002), but their use for stratigraphy is limited and controversial. Though drilling boreholes may recover material for palynological analysis from below the weathering zone (e.g. Grignani, Lanzoni \& Elatrash, 1991), it is expensive and time consuming. Where drilling is not possible, the intensive search for macrofossils is the only alternative. In the Kufra Basin, graptolites have only previously been found in boreholes through the Tanezzuft Formation in Jabal Dalma (Grignani, Lanzoni \& Elatrash, 1991). The uppermost shales of the formation have a latest Rhuddanian or earliest Aeronian age (cyphus or triangulatus biozones) based on microfossil data (Lüning et al. 1999). Exposures of the basal part of the Tanezzuft Formation were hitherto unknown in the Kufra Basin. Hence, the presence of normalograptids below the microfossil-bearing shales provides new age constraints for the basal part of the Tanezzuft Formation. As the graptolite-bearing marker bed overlies putative glacially-influenced deposits, this delimits both the temporal extent of ice cover and the onset of anoxic shale deposition in the Kufra Basin.

\section{Material and method}

This paper presents the study of over 30 graptolites preserved on 15 weathered slabs collected from exposures. Specimens CAM SM X.50191.1 to X.50191.15 were recovered from $\mathrm{a} \sim 20 \mathrm{~cm}$ thick marker bed exposed in Jabal Eghei (N 22.662307, E 19.962156) at the western margin of the Kufra Basin, southern Libya (Figs 1, 2). This bed is characterized by its more brownish colour compared to the surrounding greyish-reddish shales. In addition to the graptolite fauna, the same horizon or a horizon a few centimetres above yielded specimens X.50191.16 (N 22.71759, E 19.970541), a brachiopod similar to ?Eocoelia (D. A. T. Harper, Copenhagen, pers. comm. to G. Meinhold), 


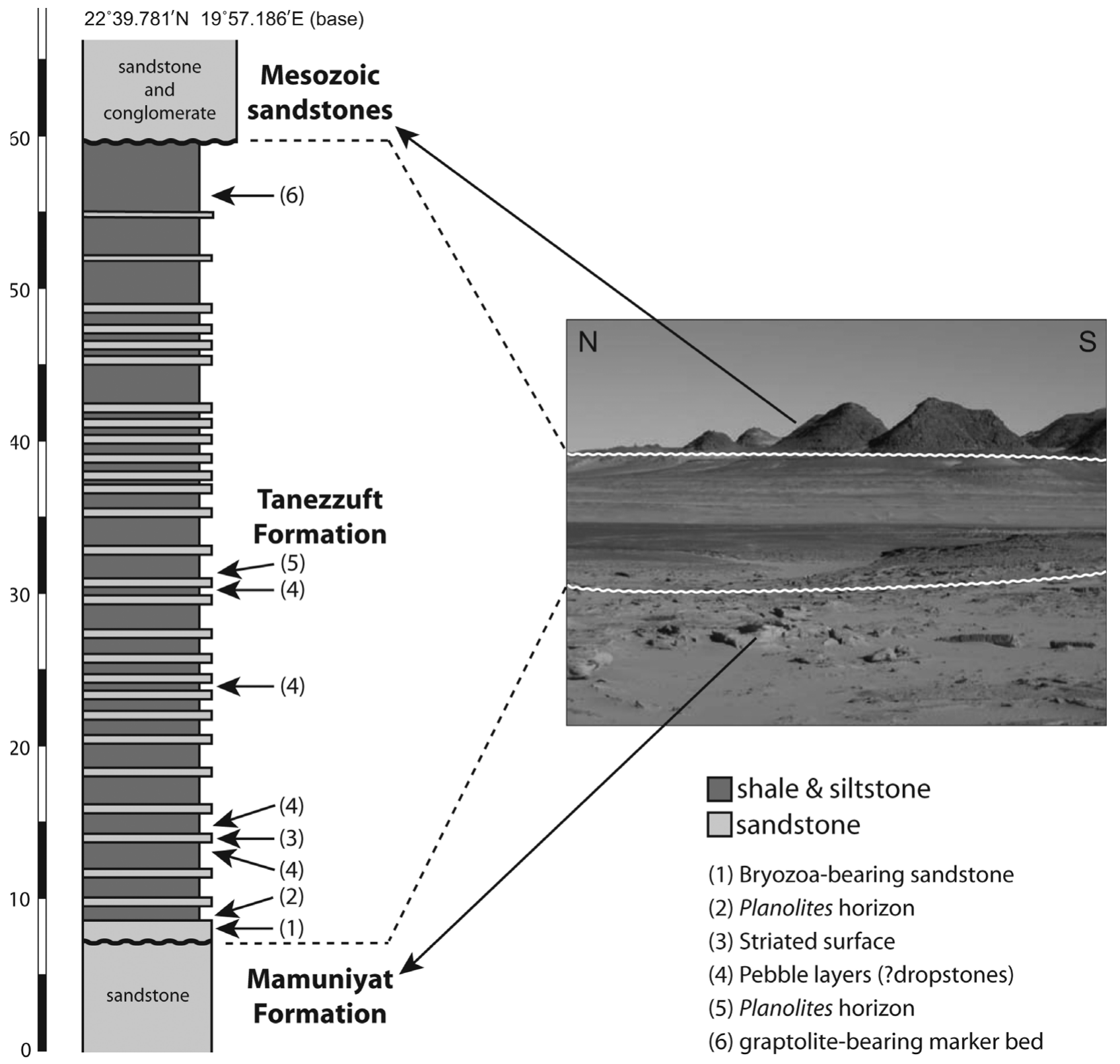

Figure 2. Schematic stratigraphic column (left) and field photograph (right) to illustrate the location of the graptolite-bearing bed within the Lower Palaeozoic succession of the western margin of the Kufra Basin.
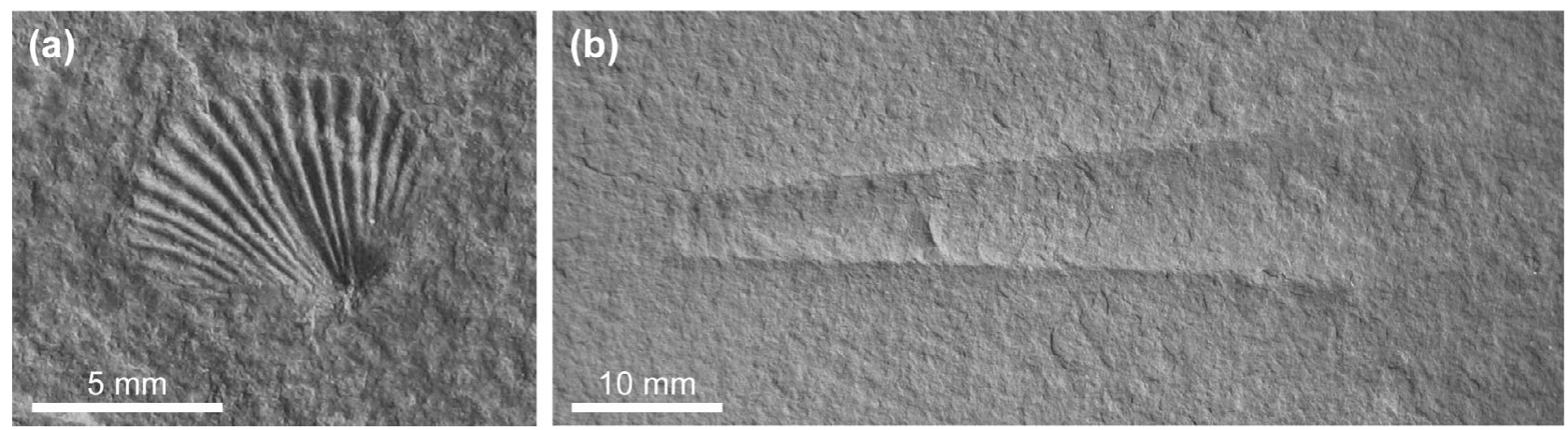

Figure 3. Shelly fossils from the Tanezzuft Formation in Jabal Eghei, western Kufra Basin. (a) Brachiopod similar to ?Eocoelia X.50191.16. (b) Orthocone, X.50191.17.

and X.50191.18 (N 22.662307, E 19.962156), an orthoconic nautiloid cephalopod (Fig. 3). The latter preserves no morphological features, precluding iden- tification at a higher taxonomic level. Though the brachiopod cannot be confidently ascribed to Eocoelia, this genus is well known from the early Silurian 
Table 1. Mean thecal measurements and standard deviations $(\sigma)$ in millimetres for the population of Normalograptus kufraensis from the graptolite-bearing bed of the Tanezzuft Formation in Jabal Eghei, Kufra Basin, Libya

\begin{tabular}{llllllll}
\hline & th1 $^{\mathbf{1}}$ & th2 $^{\mathbf{1}}$ & th3 $^{\mathbf{1}}$ & th5 $^{\mathbf{1}}$ & th10 $^{\mathbf{1}}$ & th15 $^{\mathbf{1}}$ & th20 $^{\mathbf{1}}$ \\
\hline $\mathbf{2 T R D}_{\text {mean }}$ & - & 1.77 & 1.83 & 1.97 & 2.05 & 2.07 & 2.09 \\
$\sigma_{\mathbf{2 T R D}}$ & - & 0.12 & 0.24 & 0.15 & 0.18 & 0.09 & 0.03 \\
$\mathbf{n}=$ & - & 24 & 23 & 22 & 13 & 9 & 2 \\
$\mathbf{D V W}$ & 0.83 & 0.97 & 1.04 & 1.13 & 1.20 & 1.19 & 1.29 \\
$\sigma_{\mathbf{D V W}}$ & 0.11 & 0.13 & 0.12 & 0.12 & 0.14 & 0.15 & - \\
$\mathbf{n}=$ & 24 & 23 & 24 & 22 & 16 & 8 & 1 \\
\hline
\end{tabular}

(e.g. Jin, 2003). There may be other Eocoelia-like brachiopods in older strata, however.

The graptolites were studied using reflected light microscopy, with selected specimens measured, drawn and/or photographed. Measurements and characters recorded in these graptolites (Table 1) follow those described by Loydell (2007) as useful for identifying biserial graptolites with particular attention paid to dorso-ventral widths (DVWs) and two theca repeat distances (2TRDs) sensu Howe (1983). These measurements are critical in speciating normalograptids, which tend otherwise to be very morphologically similar (cf. Melchin, 2008; Blackett et al. 2009). One major problem in the identification of biserial graptolites in high latitude sequences is that they may show considerable intraspecific variation, especially in the genus Normalograptus (e.g. Legrand, 1977, 2000, 2009; P. Legrand, unpub. Ph.D. thesis, Univ. Michel de Montaigne-Bordeaux III, 1999; Loydell, 2007) with identification requiring measurements taken at several different levels along the rhabdosome in tens of specimens.

As well as comparing the measurements of $N$. $k u$ fraensis with the type material and recent descriptions of $N$. ajjeri, $N$. angustus and $N$. arrikini, species which bear a close resemblance to it (Table 2), Table 3 compares it with width and thecal packing measurements in 44 other graptolites assigned to Normalograptus. Measurements have been extracted from descriptions in recent publications, giving as representative a view of current species concepts as possible. References to type material are also included. The list of taxa is far from exhaustive. For example, Legrand (unpub. Ph.D. thesis, Univ. Michel de Montaigne-Bordeaux III, 1999) included many taxa that have never been formally described, and the fusiform Mauritanian specimens of Underwood, Deynoux \& Ghienne (1998) have been omitted as no measurements were given in that work. Taxa such as $N$. bicaudatus (Chen \& Lin, 1978), N. bifurcatus Loydell (2007), N. lubricus (Chen \& Lin, 1978), N. minor (Huang, 1982), N. rhizinus (Li \& Yang, 1983) and $N$. trifilis (Manck, 1923) have been excluded as they are readily identified by their proximal ornamentation. Taxa with elaborate nemata are included in the list, however, as this feature may not be so readily preserved. Taxa only known from pre-Hirnantian strata have been omitted as many problems have arisen from Katian or older climacograptids being misidentified as Normalograptus (Štorch et al. 2011) and recent monographic studies of these strata are comparatively rare. This lowdiversity older fauna is listed in Goldman et al. (2011), which shows that $N$. normalis and $N$. angustus were the only species to survive the mid Katian extirpation and range into the Hirnantian when Normalograptus diversified markedly. Though the measurements given in Table 3 are the basis of much of the classification of Normalograptus, further information such as the nature of the supragenicular wall and median septum or degree of geniculation should be assessed before a confident diagnosis can be made. In addition to giving minimum and maximum values for thecal measurements (e.g. Tables 2, 3), future authors may wish to quote average measurements of mean plus or minus standard deviation (e.g. Table 1) and illustrate graphs of measurements in similar taxa (e.g. Loydell, 2007, text-fig. 9; Blackett et al. 2009, fig. 6). These techniques allow comparison and distinction more readily. Nonetheless, the data in Table 3 may be of some use for distinguishing taxa within what is often a morphologically anonymous group.

\section{Preservation and palaeoecology}

The graptolites are preserved in heavily weathered shales. They are generally cast as bas-relief impressions, though some specimens preserve periderm or the residue thereof (e.g. Fig. $4 \mathrm{a}-\mathrm{c}$ ). A few specimens are preserved in part-relief as steinkerns of iron oxides pseudomorphing pyrite (e.g. Fig. 4a). Regardless of the degree of weathering or flattening, the morphological fidelity displayed by these fossils can be very high with fusellae apparent in both 2D and 3D specimens. However, fossils occurring in coarser-grained rocks within the collection are more poorly preserved. Most graptolite assemblages display current alignment and many are in scalariform view (see Fig. 5). There is no evidence of tectonic deformation in either the rocks or fossils and the black colour of the periderm suggests little thermal alteration (cf. Goodarzi \& Norford, 1989).

The graptoloid fauna were probably cratonic invaders (sensu Finney \& Berry, 1997) that lived above the shelf rather than in the open ocean. This interpretation is consistent with the geological setting and seems sensible given the similarity in preservation and faunal composition with on-shelf assemblages from the Silurian of Saudi Arabia reported by Zalasiewicz et al. (2007). Eocoelia occurs in shallow waters (Ziegler, Cocks \& Bambach, 1968), and other eocoeliomorphs such as the one in our section could plausibly share this habitat. Pyritization or partial-pyritization of graptolites most likely reflects deposition under dysoxic conditions in which the graptolites became a locally reducing micro-environment, whilst the abundant occurrence of flattened graptolites probably 
Table 2. Comparative thecal measurements in millimetres for graptolites similar to Normalograptus kufraensis sp. nov including populations from type localities as highlighted

\begin{tabular}{|c|c|c|c|c|c|c|c|c|c|}
\hline Taxon & Data source & Locality & Age & DVW th $2^{1}$ & DVW th $5^{1}$ & DVW th $10^{1}$ & $2 \mathrm{TRD}$ th $2^{1}$ & $2 \mathrm{TRD}$ th $5^{1}$ & $2 \mathrm{TRD}$ th $10^{1}$ \\
\hline N. kufraensis & This study & Kufra Basin, Libya & ?Hirnantian & $0.70-1.20$ & $0.85-1.45$ & $1.00-1.40$ & $1.55-1.90$ & $1.60-2.10$ & $1.80-2.35$ \\
\hline N. angustus (type loc.) & Štorch, 1989 & Prague Dist, Czech Repub. & Katian & $0.80-1.00^{*}$ & $0.90-1.20$ & $0.90-1.20^{\ddagger}$ & $1.50-1.80^{\dagger}$ & $1.80-2.00$ & $2.00-2.20^{\ddagger}$ \\
\hline N. angustus & Štorch et al. 2011 & Nevada, USA & Hirnantian & $0.75-0.95^{*}$ & $1.00-1.15$ & - & $1.35-1.50$ & $1.60-2.00$ & - \\
\hline N. angustus & Loydell, 2007 & southeast Jordan & Hirn.-Rhudd. & $0.65-0.90$ & $0.95-1.10$ & - & $1.80-2.20$ & 2.15 & - \\
\hline N. angustus & Storch \& Feist, 2008 & Montagne Noire, France & Rhuddanian & $0.80-0.85$ & $1.00-1.10$ & $1.05-1.10$ & $1.80-2.05$ & $1.90-2.00$ & - \\
\hline N. angustus & Štorch \& Speragli, 1993 & Sardinia & Rhuddanian & $0.60-0.80^{*}$ & $0.80-1.10$ & $0.80-1.10^{\ddagger}$ & $1.50-1.80$ & $1.80-2.00$ & $2.00^{\ddagger}$ \\
\hline N. ajjeri (type loc.) & Legrand, 1977 & l'Oued in Djerane, Algeria & Hirnantian & $1.10-1.15$ & $1.10-1.40$ & $1.20-1.40$ & $1.00-1.60$ & 1.70 & 1.80 \\
\hline N. ajjeri & Štorch et al. 2011 & Nevada, USA & Hirnantian & $0.70-1.10^{*}$ & $1.00-1.30$ & $1.25-1.60$ & $1.50-1.85$ & $1.65-2.00$ & $1.65-2.10$ \\
\hline N. ajjeri & Legrand, unpub. Ph.D. thesis, 1999 & l'Oued in Djerane, Algeria & Hirn.-Rhudd. & $0.80-1.10$ & $1.10-1.35$ & $1.40-1.60^{\ddagger}$ & $1.20-1.60$ & $1.40-1.65$ & $1.50-2.15$ \\
\hline N. ajjeri & Štorch \& Feist, 2008 & Montagne Noire, France & Rhuddanian & $1.10-1.20$ & $1.40-1.60$ & 1.80 & $1.45-1.60$ & $1.80-1.85$ & 2.00 \\
\hline N. ajjeri & Loyde & south & Rhu & 20 & .40 & 1. & .15 & .95 & 1 . \\
\hline N. ajjeri & Loydell, $2012 b$ & Murzuq Basin, Libya & Rhuddanian & $1.05-1.25$ & $1.00-1.60$ & $1.40-1.55$ & $1.30-1.65$ & $1.40-1.80$ & $1.55-1.70$ \\
\hline N. aff. ajjeri 'A' & Legrand, unpub. Ph.D. thesis, 1999 & l'Oued in Djerane, Algeria & Hirnantian & 1.30 & 1.60 & 1.60 & 1.60 & 1.70 & 1.75 \\
\hline$N$. aff. ajjeri ' $\mathrm{B}$ ' & Legrand, unpub. Ph.D. thesis, 1999 & In Azaoua, Algeria & ?Hirn.-Rhudd. & $1.20-1.40$ & $1.15-1.80$ & $1.60-1.90$ & $1.20-1.80$ & $1.40-1.80$ & $1.60-1.80$ \\
\hline$N$. aff. ajjeri ' $\mathrm{C}$ ' & Legrand, unpub. Ph.D. thesis, 1999 & l'Oued in Djerane, Algeria & ?Rhuddanian & $0.75-0.95$ & $1.15-1.30$ & $1.55-1.80$ & $1.30-1.40$ & $1.20-1.40$ & $1.40-1.70$ \\
\hline$N$. aff. ajjeri ' $\mathrm{D}$ ' & Legrand, unpub. Ph.D. thesis, 1999 & l'Oued in Djerane, Algeria & ?Rhuddanian & $0.85-0.90$ & $0.95-1.10$ & - & $1.30-1.70$ & $1.60-1.85$ & - \\
\hline$N$. aff. ajjeri ' $\mathrm{E}$ ' & Legrand, unpub. Ph.D. thesis, 1999 & l'Oued in Djerane, Algeria & ?Rhuddanian & $1.00-1.10$ & $1.40-1.55$ & $1.55-1.60$ & $1.35-1.40$ & $1.40-1.70$ & $1.65-1.70$ \\
\hline$N$. aff. ajjeri ' $\mathrm{F}$ ' & Legrand, unpub. Ph.D. thesis, 1999 & l'Oued in Djerane, Algeria & ?Rhuddanian & 0.70 & 1.05 & & 1.50 & 1.60 & \\
\hline$N$. aff. ajjeri ' $\mathrm{H}$ ' & Legrand, unpub. Ph.D. thesis, 1999 & In Azaoua, Algeria & ?Rhuddanian & $0.80-1.00$ & $1.05-1.10$ & 1.00 & $1.75-1.80$ & 1.80 & 1.80 \\
\hline$N$. aff. ajjeri'I' & Legrand, unpub. Ph.D. thesis, 1999 & In Azaoua, Algeria & ?Rhuddanian & $0.90-1.00$ & $1.15-1.35$ & 1.40 & $1.35-1.80$ & 1.40 & $1.60-2.00$ \\
\hline$N$. aff. ajjeri ' $\mathrm{J}$ ' & Legrand, unpub. Ph.D. thesis, 1999 & In Azaoua, Algeria & ?Rhuddanian & $1.00-1.20$ & $1.25-1.60$ & $1.15-1.40$ & $1.30-1.70$ & $1.20-1.65$ & $1.60-1.80$ \\
\hline N. arrikini (type) & Legrand, unpub. Ph.D. thesis, 1999, 2009 & l'Oued in Djerane, Algeria & mid Hirn. & $0.85-0.90$ & $1.00-1.05$ & $1.10-1.30^{\ddagger}$ & 1.80 & $1.80-1.90$ & $1.85-1.95$ \\
\hline N. aff. arrikini 'A' & Legrand, unpub. Ph.D. thesis, 1999, 2009 & l'Oued in Djerane, Algeria & mid Hirn. & 1.00 & 1.35 & $1.35^{\ddagger}$ & 1.70 & 1.80 & - \\
\hline N. aff. arrikini 'B' & Legrand, unpub. Ph.D. thesis, 1999, 2009 & l'Oued in Djerane, Algeria & mid Hirn. & 1.00 & 1.20 & $1.30-1.60^{\ddagger}$ & 1.60 & 1.75 & 1.80 \\
\hline N. aff. arrikini ' $\mathrm{C}$ ' & Legrand, unpub. Ph.D. thesis, 1999, 2009 & l'Oued in Djerane, Algeria & mid Hirn. & 0.95 & 1.15 & 1.30 & 1.60 & 1.80 & 1.80 \\
\hline$N$. sp. 1 & Storch \& Feist, 2008 & Montagne Noire, France & Rhuddanian & 0.95 & 1.25 & $1.25^{\ddagger}$ & 2.00 & 1.85 & 2.00 \\
\hline
\end{tabular}

$*$-th $1^{2} ; \dagger-$ th $1^{1} ;{ }^{\ddagger}-$ distal max

All measurements are as quoted in cited texts, except for 2TRDs from Legrand (1977, 2009, unpub. Ph.D. thesis, Univ. Michel de Montaigne-Bordeaux III, 1999) and Štorch \& Feist (2008) and DVWs - excluding distal maxima recorded in Legrand (1977, 2009, unpub. Ph.D. thesis, Univ. Michel de Montaigne-Bordeaux III, 1999) and Štorch \& Feist (2008) - which were taken from figured specimens in those works. 
Table 3. Comparative thecal measurements in millimetres for normalograptids

\begin{tabular}{|c|c|c|c|c|c|c|c|}
\hline Taxon & & DVW th1 & DVW th5 & DVW dist & $2 \mathrm{TRD}$ th $2^{1}$ & $2 \mathrm{TRD}$ th $5^{1}$ & 2TRD dist \\
\hline N. acceptus (Koren' \& Mikhaylova, 1980) & {$[4]$} & $0.40-0.60$ & $0.60-0.85$ & $0.75-0.95$ & $1.05-1.55^{*}$ & & $1.40-1.80$ \\
\hline N. ajjeri (Legrand, 1977) & [11] & $0.70-1.10$ & $1.00-1.60$ & $1.10-1.80$ & $1.00-1.85$ & $1.35-2.00$ & $1.50-2.15$ \\
\hline N. angustus (Perner, 1895) & [11] & $0.60-1.00$ & $0.80-1.20$ & $1.05-1.15$ & $1.35-2.20$ & $1.80-2.15$ & $2.00-2.20$ \\
\hline N. arrikini (Legrand, 2009) & [11] & $0.85-0.90^{*}$ & $1.00-1.05$ & $1.10-1.30 \S$ & 1.80 & $1.80-1.90$ & $1.85-1.95$ \\
\hline N. avitus (Davies, 1929) & [3] & $0.70-0.90$ & & $1.50-1.80$ & $1.60-2.00$ & & $2.00-2.20$ \\
\hline N. cortoghiaensis (Štorch \& Sperlagi, 1993) & {$[7]$} & 0.90 & 1.20 & & 1.65 & 1.75 & \\
\hline N. crassus Štorch \& Feist (2008) & {$[10]$} & $1.00-1.35$ & $1.70-1.90$ & $1.70-1.90$ & $1.35-1.95$ & $1.70-2.00$ & \\
\hline N. daedalus (Mu \& Ni, 1983) & [3] & $0.70-0.90$ & & $1.80-2.30$ & $1.30-1.50$ & & $1.80-2.00$ \\
\hline N. elegantus (Mu \& Ni, 1983) & {$[10]$} & $0.90-1.15$ & $1.40-1.65$ & $1.50-1.85 \S$ & $1.00-2.00$ & $1.90-2.30$ & $2.10-2.45$ \\
\hline N. extraordinarius (Sobolevskaya, 1974) & [3] & $1.10-1.50$ & & $2.90-3.50$ & $1.50-1.70$ & & $1.90-2.20$ \\
\hline N. extraordinarius (Sobolevskaya, 1974) & {$[10]$} & $0.90-1.20$ & $1.40-2.00$ & $1.70-2.70 \S$ & $1.35-1.85$ & $1.50-2.10$ & $1.60-2.20 \S$ \\
\hline N. gelidus Legrand (2009) & {$[6]$} & 0.80 & & $1.60-2.00 \S$ & $1.60-2.00^{*}$ & & $1.80-2.40$ \\
\hline N? guihouensis (Chen \& Lin, 1978) & [3] & $0.75-0.85$ & & $1.90-2.10$ & $1.50-1.70$ & & $1.90-2.20$ \\
\hline N. aff. indivisis (Davies, 1929) & [3] & $0.75-0.80$ & & $1.15-1.90 \S$ & $1.25-1.50$ & & $1.50-1.80$ \\
\hline N. jidelensis (Koren’ \& Mikhaylova, 1980) & [4] & $0.65-0.90$ & $0.90-1.25$ & $1.1-1.35$ & $1.08-1.40^{*}$ & & $1.2-1.55$ \\
\hline N. kufraensis nov. sp. & [11] & $0.70-1.20^{*}$ & $0.85-1.45$ & $1.00-1.40$ & $1.55-1.90$ & $1.60-2.10$ & $1.80-2.35$ \\
\hline N. laciniosus (Churkin \& Carter, 1970) & [3] & $0.75-0.90$ & & $1.60-1.80$ & $1.20-1.60$ & & $1.50-2.00$ \\
\hline N. larini Koren' \& Melchin (2000) & [4] & $0.60-0.70$ & $0.90-1.10$ & $1.00-1.15$ & $1.25-1.55^{*}$ & & $1.25-1.55$ \\
\hline N. larini Koren’ \& Melchin (2000) & [7] & 0.65 & 1.00 & & 1.60 & 1.75 & \\
\hline N. legrandi Koren' \& Rickards (2004) & {$[5]$} & $0.40-0.58$ & 0.60 & & $0.83-1.05^{*}$ & & \\
\hline N? lungmaensis (Sun, 1933) & [3] & $1.00-1.10$ & & $2.10-2.40$ & $1.40-1.90$ & & 2.00 \\
\hline N? magnus (H. Lapworth, 1900) & [12] & $0.60-1.00$ & $1.40-1.80$ & $1.70-4.10 \S$ & $1.30-1.50$ & $1.20-1.70$ & $1.40-1.90 \S$ \\
\hline N. medius (Törnquist, 1897) & [3] & $1.10-1.30$ & & $2.10-2.40$ & $1.30-1.60$ & & $1.60-2.00$ \\
\hline N. medius (Törnquist, 1897) & [7] & $0.90-1.10$ & $1.30-1.75$ & $1.60-1.85 \S$ & $1.40-1.75$ & $1.45-1.75$ & $1.45-1.75 \S$ \\
\hline N. melchini Koren' \& Rickards (2004) & [5] & $0.32-0.46$ & & $0.32-0.46$ & $1.02-1.36^{*}$ & & \\
\hline N. mirnyensis (Obut \& Sobolevskaya, 1967) & [3] & $0.60-0.85$ & & $1.05-1.20$ & $1.30-1.60$ & & 1.80 \\
\hline N. mirnyensis (Obut \& Sobolevskaya, 1967) & [4] & $0.55-0.60$ & $0.80-0.90$ & $0.95-1.10$ & $1.25-1.55^{*}$ & & $1.35-1.75$ \\
\hline N. mirnyensis (Obut \& Sobolevskaya, 1967) & [7] & $0.65-0.80$ & $0.75-1.05$ & $0.95-1.10 \S$ & $1.45-1.70$ & $1.45-1.90$ & $1.60-1.65 \S$ \\
\hline N. mirnyensis (Obut \& Sobolevskaya, 1967) & {$[10]$} & $0.70-1.10$ & $1.05-1.15$ & 1.20 & $1.20-1.60$ & $1.45-1.55$ & \\
\hline N. normalis (C. Lapworth, 1877) & {$[7]$} & $0.80-1.05$ & $1.20-1.75$ & $1.60-1.85 \S$ & $1.40-1.75$ & $1.45-1.75$ & $1.45-2.00 \S$ \\
\hline N. cf. normalis (C. Lapworth, 1877)** & [7] & $0.85-1.20$ & $1.30-1.75$ & $1.25-1.60 \S^{* *}$ & $1.30-1.55$ & $1.40-1.75$ & $1.45-1.90 \S$ \\
\hline N. nseirati Legrand (2009) $)^{* *}$ & {$[6]$} & 1.20 & $2.00-2.40 \ddagger$ & $2.60-3.20 \S^{* *}$ & $1.60^{*}$ & & 2.00 \\
\hline N. ojsuensis (Koren' \& Mikhaylova, 1980) & [3] & $1.00-1.40$ & & $2.10-2.40$ & $1.60-1.90$ & & $2.10-2.30$ \\
\hline N. ojsuensis (Koren' \& Mikhaylova, 1980) & {$[10]$} & $0.90-1.15$ & $1.15-1.70$ & $1.50-2.20 \S$ & $1.40-1.85$ & $1.60-2.00$ & $1.70-2.30$ \\
\hline N? parvulus (H. Lapworth, 1900) & {$[1]$} & 0.90 & $1.25 \ddagger$ & & 1.50 & & \\
\hline N? parvulus (H. Lapworth, 1900) & [2] & $0.70-1.00$ & $1.05-1.60$ & $1.25-1.70 \S$ & $1.05-1.65$ & $1.20-1.80$ & $1.15-1.75 \S$ \\
\hline N? cf. parvulus (H. Lapworth, 1900) & [1] & $0.70-1.00$ & $0.90-1.50$ & $0.90-1.20 \S$ & $1.10-1.60$ & $1.50-1.80^{\ddagger}$ & $1.50-1.90^{\|}$ \\
\hline$N ?$ aff. parvulus (H. Lapworth, 1900) & [1] & $0.60-1.00$ & $0.90-1.50$ & $0.90-1.20 \S$ & $1.50-2.20$ & $1.70-2.40^{\ddagger}$ & $1.90^{\|}$ \\
\hline N? persculptus (Elles \& Wood, 1907) & {$[1]$} & $0.70-1.10$ & $1.00-1.70$ & $1.10-2.00 \S$ & $1.30-2.00$ & $1.50-2.30^{\ddagger}$ & $1.70-2.60^{\|}$ \\
\hline N? persculptus (Elles \& Wood, 1907) & [2] & $0.85-1.15$ & $1.05-1.60$ & $1.40-2.25 \S$ & $1.25-1.70$ & $1.25-2.10$ & $1.80-2.30 \S$ \\
\hline N? cf. persculptus (Elles \& Wood, 1907) & {$[1]$} & $0.80-1.20$ & $1.20-1.60$ & $1.20-1.90 \S$ & $1.20-1.50$ & $1.50-1.90^{\ddagger}$ & $1.70-2.10^{\|}$ \\
\hline N. premedius (Waern, 1948) & [8] & 0.60 & 0.95 & $1.25 \S$ & 1.95 & 2.40 & $2.50 \S$ \\
\hline N. pretilokensis Legrand (2009) & [6] & $1.10-1.20$ & $1.60 \ddagger$ & $1.80-2.30$ & 1.809 & & $1.800^{\circ}$ \\
\hline N. rectangularis (M'Coy, 1850) & [7] & $0.60-1.05$ & $1.20-1.55$ & $1.50-1.80 \S$ & & & \\
\hline N. rectangularis (M'Coy, 1850) & [9] & $0.75-0.95$ & $1.20-1.90$ & $1.50-2.20 \S$ & $1.40-1.70$ & $1.40-1.80$ & $1.40-1.80$ \\
\hline N. skeliphrus Koren' \& Melchin (2000) & [4] & $0.40-0.60$ & $0.60-0.75$ & $0.60-0.80$ & $1.20-1.55^{*}$ & & $1.20-1.55$ \\
\hline N. sobolevkayae Koren' \& Rickards (2004) & {$[5]$} & $0.37-0.46$ & & & $0.95-1.29^{*}$ & & \\
\hline N. targuii Legrand (2001) & [7] & $0.70-1.00$ & $1.00-1.45$ & $1.05-1.60 \S$ & $1.30-1.80$ & $1.40-1.85$ & $1.40-2.10 \S$ \\
\hline N. tilokensis (Legrand, 1986) & [9] & $0.90-1.15$ & $1.50-2.05$ & $1.60-2.65 \S$ & $1.45-1.90$ & $1.55-2.00$ & $1.70-2.05 \S$ \\
\hline N. transgrediens (Waern, 1948) & [7] & 0.65 & 1.15 & & 1.45 & 1.50 & \\
\hline N. ugurensis (Koren’ \& Mikhaylova, 2000) & [3] & $0.80-1.00$ & & $1.60-1.80$ & $1.30-1.60$ & & $1.80-2.20$ \\
\hline N. wangjiawanensis (Mu \& Lin, 1984) & [3] & $0.70-1.00$ & & $1.70-1.90 \S$ & $1.50-2.00$ & & $1.80-2.20$ \\
\hline N? wyensis Zalasiewicz \& Tunnicliff (1994) & [12] & $0.60-0.80$ & $0.90-1.20$ & $1.40 \S$ & $1.10-1.50$ & & $1.60 \S$ \\
\hline$N$. sp. of Štorch et al. (2011) & {$[10]$} & $0.80-0.90^{*}$ & & $1.00-1.20$ & 1.709 & & 1.709 \\
\hline
\end{tabular}

* - proximal; $\dagger-$ th $4 ; \ddagger-$ th $6 ; \S-$ th $10 ; \|-$ th $11 ; \boldsymbol{\Phi}$ - throughout; ${ }^{* *}$ - fusiform

[1] - Hirnantian-Rhuddanian of central Wales, UK (Blackett et al. 2009); [2] - localities listed in Loydell (2007, text-fig. 9) as given in Blackett et al. (2009); [3] - Hirnantian of the Yangtze Region, China (Chen et al. 2005); [4] - Rhuddanian of the Kurama Range,

Uzbekistan (Koren' \& Melchin, 2004); [5] - Llandovery of the southern Urals, Russia (Koren' \& Rickards, 2004); [6] - Hirnantian of Algeria (Legrand, 2009); [7] - Hirnantian-Rhuddanian of Jordan (Loydell, 2007); [8] - Hirnantian or Llandovery of the Southern Uplands, Scotland (Loydell, 2007); [9] - Rhuddanian of the Murzuq Basin, Libya (Loydell, 2012b); [10] - Hirnantian of Nevada, USA (Štorch et al. 2011); [11] - Table 2 (this study); [12] - Rhuddanian of the Wye Valley, Wales, UK (Zalasiewicz \& Tunnicliff, 1994). All measurements are as quoted in descriptions or tables. An Excel spreadsheet version of these data is available from the authors on request.

represents preservation in a fully anoxic environment (Underwood, 1992; Underwood \& Bottrell, 1994; A. A. Page, unpub. Ph.D. thesis, Univ. Leicester, 2007; Zalasiewicz et al. 2007; Loydell et al. 2009). Though causes of anoxia are various, transgressive black shales are common in shelf successions of this age, arguably deposited in response to deglaciation (Armstrong et al. 2005; Page et al. 2007).

\section{Systematic palaeontology}

Family NORMALOGRAPTIDAE Štorch \& Serpagli, 1993 emend. Melchin et al. (2011).

Genus Normalograptus Legrand (1987) emend. Melchin \& Mitchell (1991) emend. Melchin et al. (2011).

Type species. [OD] Climacograptus scalaris var. normalis Lapworth (1877). 


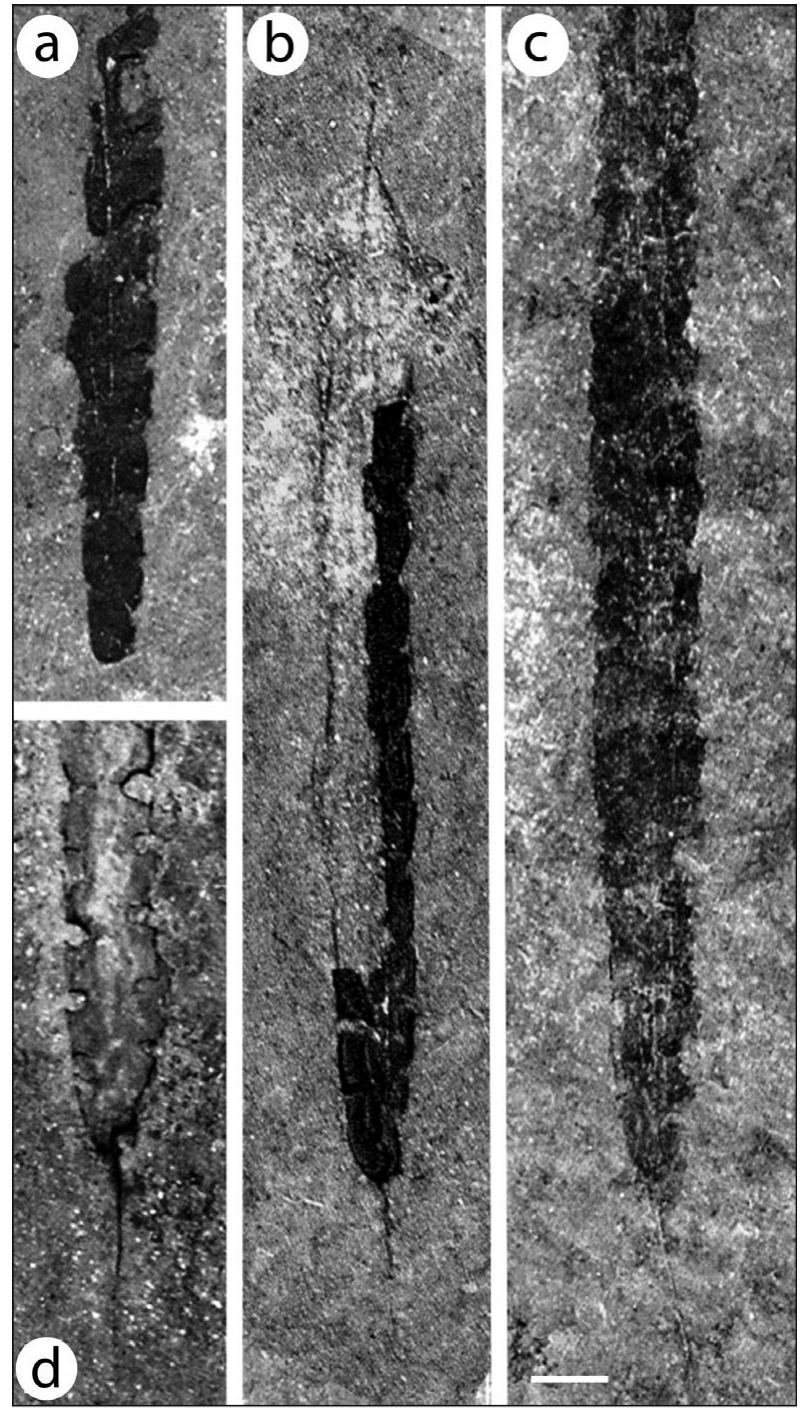

Figure 4. Photomicrographs of Normalograptus kufraensis sp. nov. from the graptolite-bearing bed of the Tanezzuft Formation in Jabal Eghei, western Kufra Basin. Specimen numbers: (a) X.50191.10, (b) X.50191.6b, (c) X.50191.6a, (d) X.50191.13. Scale bar $=1 \mathrm{~mm}$.

Diagnosis. Biserial graptolites of astogenic Pattern H with unornamented climacograptid thecae having straight or concave interthecal septa throughout the rhabdosome and a full median septum, which may be delayed.

Normalograptus kufraensis sp. nov.

Figures $4 \mathrm{a}-\mathrm{d}, 5 \mathrm{a}-\mathrm{h}$

Holotype. Specimen CAM SM X.50191.3c (Fig. 5b) from the Tanezzuft Formation, Jabal Eghei, Libya (N 22.662307, E 19.962156).

Material. 30+ graptolites on samples CAM SM X.50191.1 to X.50191.15, of which 23 were sufficiently well-preserved for detailed morphological study, being CAM SM X.50191.1ac, X.50191.3a-f; X.50191.4a, X.50191.6a-b, X.50191.7ab, X.50191.8a, X.50191.9a; X.50191.10a, X.50191.12a, X.50191.13a, X.50191.14a-b and X.50191.15a-b. These specimens are stored in the Sedgwick Museum, University of Cambridge, UK.

Locality and horizons. All specimens come from a single marker bed at the western margin of the Kufra Basin, southern Libya (Figs 1, 2).
Preservation. As above.

Etymology. After the Kufra Basin where the graptolites were found.

Diagnosis. Normalograptid with a long virgella, long, straight nema, climacograptid thecae with long, parallel supragenicular walls and a full, straight median septum; 2TRDs and DVWs range, respectively, between 1.55 $1.90 \mathrm{~mm}$ and $0.70-1.20 \mathrm{~mm}$ at theca $2^{1}$, between 1.60 $2.10 \mathrm{~mm}$ and $0.85-1.45 \mathrm{~mm}$ at theca $5^{1}$, and $1.90-2.35 \mathrm{~mm}$ and $1.05-1.45 \mathrm{~mm}$ distally. Maximum width achieved at or around the sixth thecal pair.

Description. Mature rhabdosomes are up to $24 \mathrm{~mm}$ long consisting of 25 thecal pairs. The rhabdosome widens rapidly achieving constant maximum DVWs and 2TRDs by thecae 4-6. The nema and virgella protrude up to at least 5 and $7 \mathrm{~mm}$ from either end of the rhabdosome, respectively. The undivided virgella runs straight down following the line of the median septum in all but one example. The sicula ranges between 1.60 and $2.40 \mathrm{~mm}$ in length, and 0.30 and $0.45 \mathrm{~mm}$ in width; its apex typically lies between thecae $2^{1}-2^{2}$, though rarely it may reach slightly more distally than the level of theca $2^{2}$. Theca $1^{1}$ grows down $0.20-0.30 \mathrm{~mm}$ below the sicula aperture and is $0.90-1.20 \mathrm{~mm}$ long, whilst the length of the exposed margin of the sicula below theca $1^{2}$ is 0.25 $0.45 \mathrm{~mm}$. Thecae are of typical climacograptid form with sharp genicula and long, straight supragenicular walls that run parallel to the median septum. The thecal apertures are horizontal and a complete median septum is apparent in most specimens. A summary of 2TRDs and DVWs for these specimens is given in Table 1 and Figure 6.

Discussion. With no bimodality observed in its populations and little variation between slabs, N. kufraensis clearly represents a single taxon, dissimilar in measurements to comparable graptolites (Tables 2, 3). Though $N$. kufraensis exhibits a considerable range of DVW and $2 \mathrm{TRD}$ variation, this may in part reflect the style of preservation, with some specimens flattened and others in relief. But such a range of variation is typical in normalograptid specimens from high palaeolatitudes (Loydell, 2007) and comparable to the range of variation of three-dimensionally preserved material from lower palaeolatitudes (e.g. Blackett et al. 2009). The smaller range of variation seen in other taxa included in Table 2 may reflect the fact that many of these data are taken from measurements of figured specimens rather than large populations. Likewise, the range in virgella length apparent in $N$. kufraensis is typical of that in other normalograptids (see Chen et al. 2005; Loydell, 2007). This may reflect an ecophenotypic response to the local hydrodynamic regime as Rickards et al. (1998) showed that the virgella served to align the graptolite to the ambient current. Though some specimens appear slightly fusiform (e.g. Fig. 5a, $\mathrm{h}$ ), this is not apparent in most, especially not in any in biprofile preservation, suggesting it may be an artefact of flattening. The preponderance of subscalariform preservation may indicate that $N$. kufraensis had similar dorsoventral and lateral widths.

$N$. kufraensis belongs to a small distinctive clade of slender, elongate normalograptids with climacograptid thecae and long nemata and virgellae that superficially resemble the unadorned climacograptid Styracograptus Storch et al. (2011). N. kufraensis may be confidently assigned to Normalograptus based on its narrow triangulate proximal end, however. Other more subtle distinctions between it and Styracograptus include simple distal thecal ontogeny from theca $2^{1}$, a typical unflexed graptoloid sicula and the absence of cross bars on Normalograptus nemata (Goldman et al. 


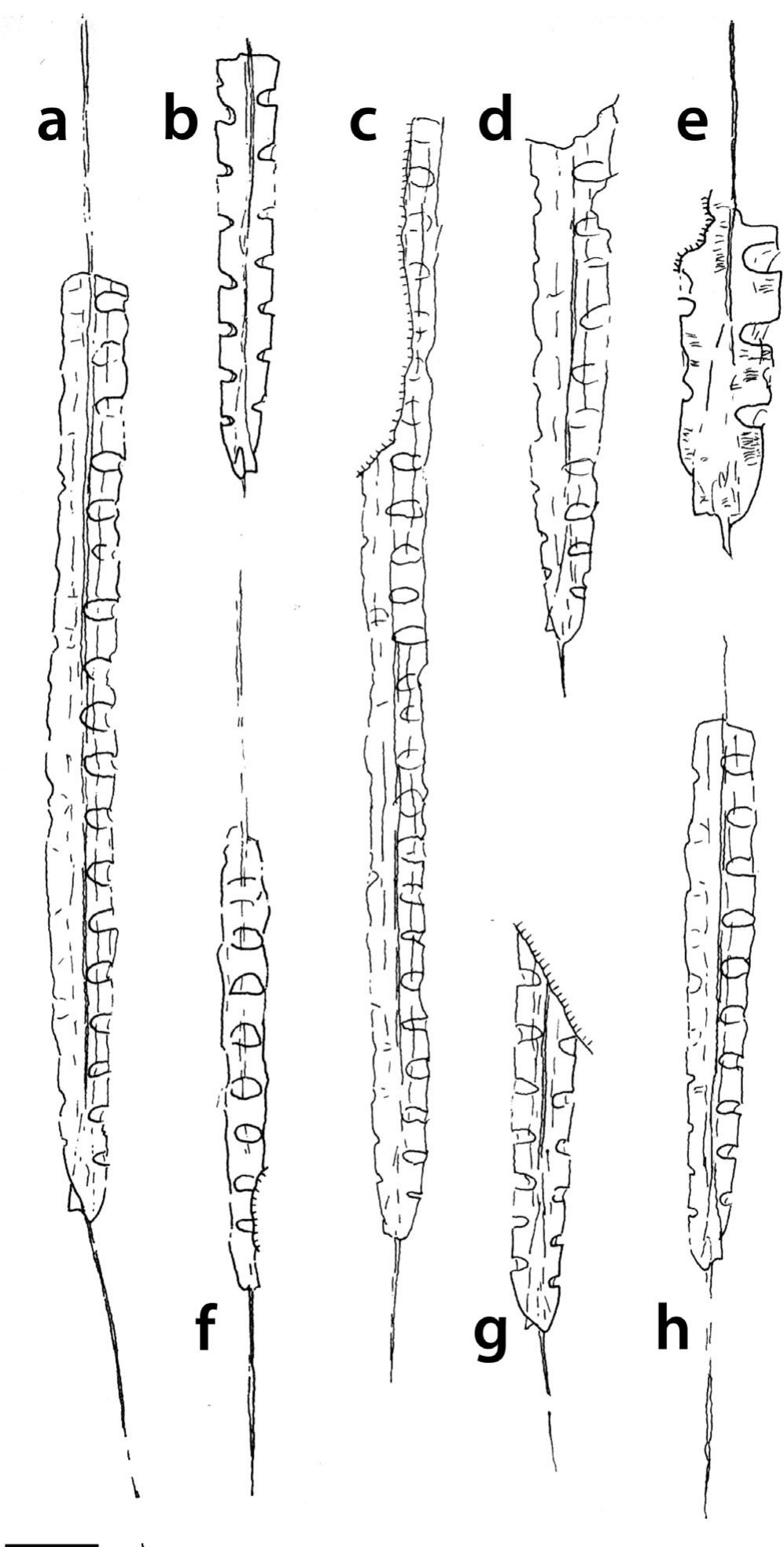

Figure 5. Camera lucida drawings of Normalograptus kufraensis sp. nov. from the graptolite-bearing bed of the Tanezzuft Formation in Jabal Eghei, western Kufra Basin. Specimen numbers: (a) X.50191.6a, (b) X.50191.3c, holotype, (c) X.50191.1, (d) X.50191.13, (e) X.50191.3e, (f) X.50191.3d, (g) X.50191.14b, (h) X.50191.3a. Scale bars = $2 \mathrm{~mm}(\mathrm{a}-\mathrm{d}, \mathrm{f}-\mathrm{h}) ; 1 \mathrm{~mm}(\mathrm{e})$.

2011). The distinction between the genera has simplified the synonymy of the Styracograptus-like normalograptids, with many Katian forms reassigned to Styracograptus. The specimens from Jabal Eghei cannot be accommodated in any established species: Table 2 compares its width and thecal packing with the Styracograptus-like normalograptids $N$. ajjeri, $N$. angustus and N. arrikini, and Table 3 compares it with other normalograptids. The elongate graptolite $N$. rectangularis is larger in all dimensions, and Normalograptus normalis like many other normalograptids is significantly more robust. Others differ markedly.

Though there is some overlap between the measurements of $N$. kufraensis and specimens of $N$. ajjeri, $N$. angustus and $N$. arrikini, the range of variation in N. kufraensis 


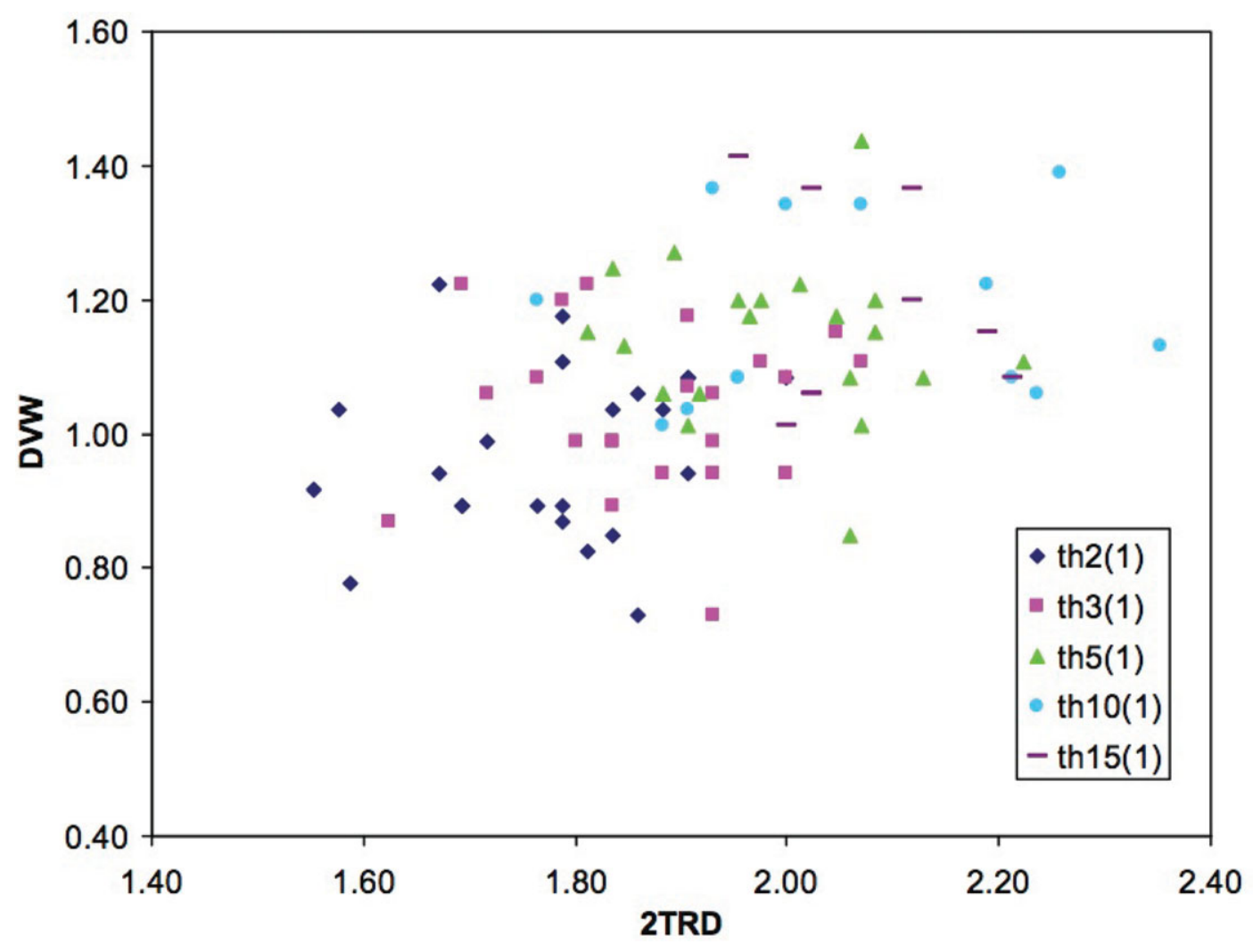

Figure 6. (Colour online) Scatter plot of dorso-ventral widths (DVW) and two theca repeat distances (2TRD) measured on Normalograptus kufraensis from the Lower Palaeozoic succession of Jabal Eghei, western Kufra Basin.

is centred almost exactly on the 'gap' in morphospace between the other taxa. N. angustus (Perner, 1895) is too gracile, whilst the sister species $N$. ajjeri (Legrand, 1977) and N. arrikini Legrand (2009) have their thecae too closely spaced (Table 2), as is true of many other slender normalograptids (cf. Loydell, 2007; Blackett et al. 2009). Working on material from the late Ordovician of Nevada, Storch et al. (2011) observed that $N$. angustus is more strongly geniculate than $N$. ajjeri, and that it may have an undulating median septum. $N$. kufraensis is intermediate in geniculation and has a fully straight median septum. Though there is some overlap between their the 2TRDs of specimens of $N$. ajjeri from Nevada and N. kufraensis, the Libyan graptolites have their thecae significantly more widely spaced on average (Tables 1,2). By having climacograptid thecae, $N$. kufraensis appears more similar to $N$. ajjeri than $N$. arrikini. But as distortion in flattening can result in climacograptid thecae taking on a glyptograptid appearance (Briggs \& Williams, 1981; Loydell, 2007), this distinction could be artefactual: the Algerian taxa are very similar indeed. Whilst Legrand (unpub. Ph.D. thesis, Univ. Michel de MontaigneBordeaux III, 1999) reported many 'aff.' forms of either taxon (Table 2), none of these agree with the dimensions of $N$. kufraensis. Although the Libyan graptolites appear to conform to $N$. sp. 1 of Štorch \& Feist (2008) in terms of their measurements (Table 2), the latter, which is only known from a single specimen, has a highly asymmetrical proximal end precluding synonymy. Thus $N$. kufraensis clearly represents a new species.

$N$. kufraensis may have plausibly evolved from $N$. angustus in the latest Ordovician. The $N$. angustus lineage undergoes a considerable reduction in rhabdosome width in the Silurian (cf. Rickards, 1970; Hutt, 1974; Štorch, 1989; Štorch \& Speragli, 1993; Chen et al. 2005; Loydell, 2007; Table 2), with the dimensions of some broader Ordovician forms of
$N$. angustus overlapping with $N$. kufraensis a little (Table 2). Until this lineage has been explored in more detail, it is impossible to conclude as to whether certain specimens assigned to $N$. angustus may be better ascribed to $N$. kufraensis. N. angustus is both temporally and geographically wide ranging. $N$. ajjeri is also relatively long-lived, with Loydell (2007) sensibly synonymizing almost all previous reports of $N$. normalis with it. He did not, however, discuss Katian reports of $N$. normalis (e.g. Williams, 1982a; Chen et al. 2000; Rickards, 2002), which might push its first appearance somewhat earlier. It seems at present, however, that $N$. kufraensis is best viewed as an intermediate between the broader Ordovician specimens of the $N$. angustus lineage and the sister species $N$. ajjeri and $N$. arrikini, which have a Hirnantian or younger age. This is certainly consistent with the pattern of Normalograptus biogeography and evolution: aside from $N$. angustus, normalograptids with climacograptid thecae are unknown between the mid Katian and Hirnantian, when they diversified considerably (Goldman et al. 2011).

\section{Biostratigraphic age constraints and deglacial anoxia}

Graptolites from Jabal Eghei can be confidently assigned to the genus Normalograptus, which provides lower and upper bounds for the age of the graptolitebearing marker bed and hence for the Tanezzuft Formation in Jabal Eghei. In the UK, Normalograptus is known from the murchisoni Zone of the Darriwilian (late Middle Ordovician) through to at least the magnus Zone of the Aeronian (mid Llandovery, Silurian) (Zalasiewicz et al. 2009). However, graptolites referred to the genus Glyptograptus extend to the griestoniensis 


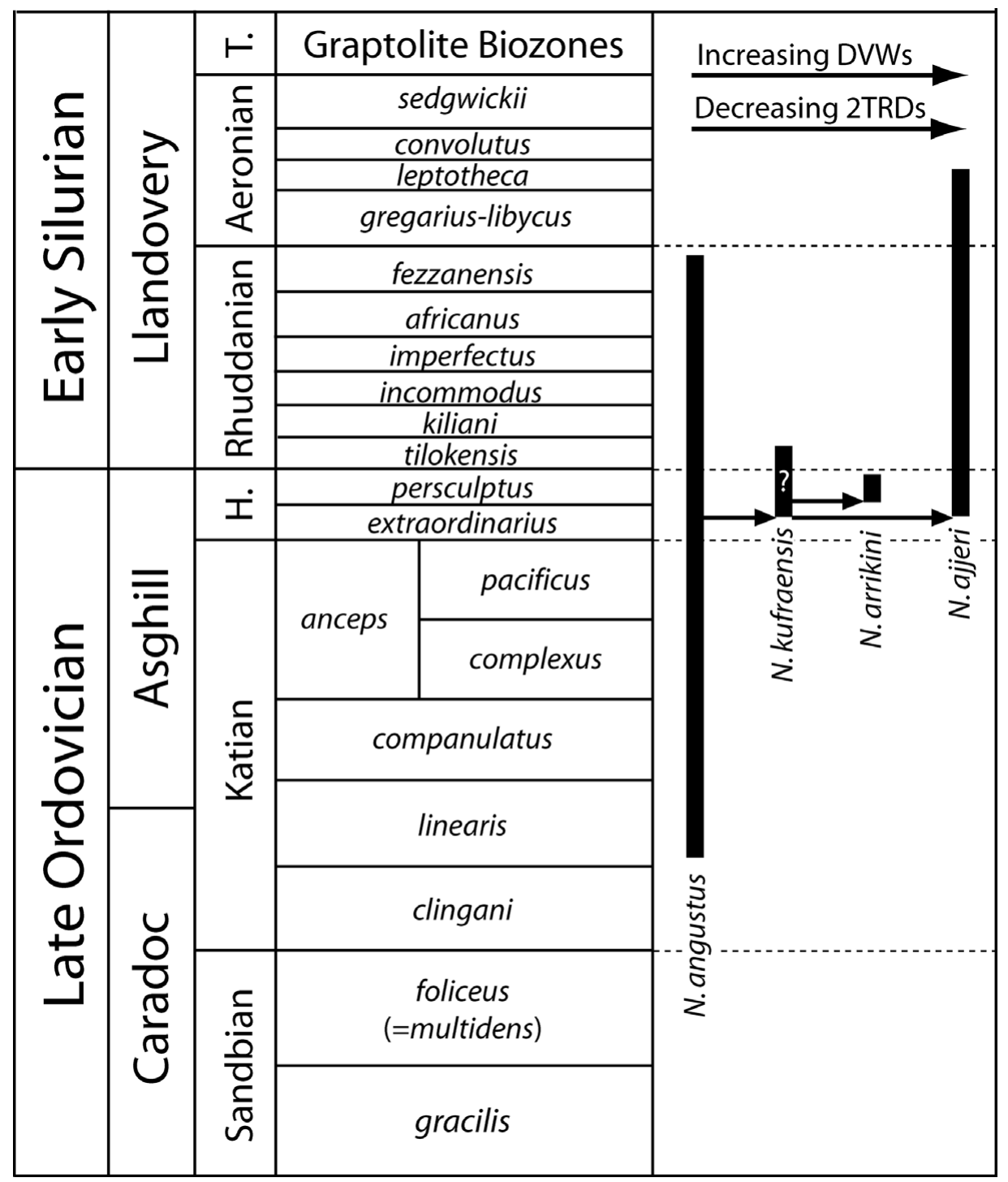

Figure 7. Stratigraphic range of the graptolites Normalograptus angustus, $N$. ajerri and $N$. arrikini with proposed relationship to $N$. kufraensis illustrated. The biozonation and correlation between regions follows Loydell (2012a). See text for other references.

Zone of the Telychian (late Llandovery, Silurian) (Zalasiewicz et al. 2009) and Melchin (1998) showed that Llandovery 'glyptograptids' with a full distal median septum should be assigned to Normalograptus. Some of the earlier occurrences of Normalograptus may in fact be Styracograptus (Goldman et al. 2011). At first sight though, N. kufraensis may potentially be of anything from Darriwilian to Llandovery in age.

The oldest age for $N$. kufraensis may be in principle inferred from stratophenetic considerations. As noted above, $N$. kufraensis is best viewed as an intermediate between the Ordovician branch of the $N$. angustus lineage and Legrand's sister species $N$. ajjeri and N. arrikini. Both $N$. angustus and $N$. ajjeri are long-ranging taxa, whereas $N$. arrikini is restricted to the latest Ordovician (Fig. 7). N. angustus is known from the earlier part of the linearis Zone (Katian, late Ordovician) to the cyphus Zone (Rhuddanian, early Silurian) (see Rickards, 1970; Hutt, 1974; Zalasiewicz et al. 2009; Goldman et al. 2011, who reassigned reports of clingani Zone occurrences such as in Williams,
$1982 b$ to Styracograptus miserabilis). Loydell (2007) states that $N$. ajjeri ranges from the Hirnantian to early Aeronian. If $N$. kufraensis was an evolutionary intermediate between broader Ordovician forms of $N$. angustus and $N$. ajjeri itself, then $N$. kufraensis must have originated in the Hirnantian suggesting the outcrop in Jabal Eghei could be of Hirnantian (persculptus Zone) or younger age. However, further data either on the stratigraphy of the Tanezzuft Formation or on the evolution of the $N$. angustus and $N$. ajjeri-N. arrikini lineages are needed for this to be confirmed.

The uppermost shales of the Tanezzuft Formation have a latest Rhuddanian or earliest Aeronian age (cyphus or triangulatus biozones) (Lüning et al. 1999). Grignani, Lanzoni \& Elatrash (1991) mentioned Climacograptus medius Törnquist from core samples of well KW-2, drilled by AGIP in Jabal Asba in 1975. The occurrence of this graptolite suggests a late Ordovician (Hirnantian) or early Llandovery age (Rhuddanian to early Aeronian) for the studied core 
interval (Lüning et al. 1999). These data indicate that the graptolite marker bed must have been deposited before the early Aeronian. The graptolite-bearing bed occurs above a glaciogenic unconformity thought to be of Hirnantian age (Le Heron \& Howard, 2010). Given the stratophenetic argument that $N$. kufraensis emerged from the $N$. angustus lineage in the latest Ordovician, the lowermost shales of the Tanezzuft Formation were deposited at sometime in or after the Hirnantian and before the earliest Aeronian.

The sedimentary succession at Jabal Eghei records deglaciation and a short-lived episode of transgressive anoxia (Le Heron et al. In press). This is seen elsewhere in northern Gondwana and at lower latitudes in which the onset of anoxia occurs in the persculptus Biozone (Armstrong et al. 2005; Page et al. 2007). However, the temporal extent of the unconformity in this section has yet to be determined and the Rhuddanian also contains notable intervals of anoxia. Though the biostratigraphic resolution is currently too coarse to definitively place these shales in the Hirnantian, and the conventional view is that marine flooding of the Kufra Basin occurred in the early Silurian (Lüning et al. 1999), there is increasing evidence pointing to a prolonged deglacial oceanic anoxic episode originating in the latest Ordovician (Page et al. 2007). In Jabal Eghei, however, the anoxia was short-lived.

\section{Conclusions}

An assemblage of Normalograptus kufraensis nov. sp. - an intermediate between $N$. angustus (Perner) and $N$. ajjeri (Legrand) - has been recovered from exposures in the western Kufra Basin of southern Libya. Although it is morphologically similar to the long-ranging graptolites $N$. angustus and $N$. ajjeri, stratophenetic considerations suggest $N$. kufraensis from Jabal Eghei may have been of Hirnantian age or younger. If so, this would show that the basal part of the Tanezzuft Formation is exposed at the western margin of the Kufra Basin. Thus, following late Ordovician glaciation, major marine flooding of the Kufra Basin may have begun in the Hirnantian or earliest Rhuddanian (see also Grignani, Lanzoni \& Elatrash, 1991; CASP, unpub. data), plausibly earlier than thought. Establishing the relationship between anoxia, deglaciation and organic carbon burial at this time may further constrain our understanding of the Early Palaeozoic Icehouse climate (Page et al. 2007).

Acknowledgements. We gratefully thank Yousef Abutarruma, Ramadan Aburawi, Ahmed I. Asbali, Ibrahim Baggar, Faraj Said and Bindra Thusu for their scientific support and guidance for the project work in Libya. We also would like to thank the logistics team, provided by Bashir Grenat, for assistance in the field. The administrative and logistical support of staff at LPI is gratefully acknowledged. David Loydell, Barrie Rickards and Petr Štorch are thanked for their comments and provision of literature. Mike Melchin and Jan Zalasiewicz's advice and constructive reviews further improved the manuscript. The consortium of subscribing oil and gas companies is thanked for its financial support to the CASP Southern Basins of Libya Project. This is Cambridge Earth Sciences contribution number ES.2572.

\section{References}

Armstrong, H. A., Turner, B. R., Makhlouf, I. M., Weedon, G. P., Williams, M., Al Smadi, A. \& ABU SALAH, A. 2005. Origin, sequence stratigraphy and depositional environment of an upper Ordovician (Hirnantian) deglacial black shale, Jordan. Palaeogeography, Palaeoclimatology, Palaeoecology 220, 273-89.

Bellini, E., Giori, I., Ashuri, O. \& Benelli, F. 1991. Geology of Al Kufra Basin, Libya. In The Geology of Libya, Vol. 6 (eds M. J. Salem, A. M. Sbeta \& M. R. Bakbak), pp. 2155-84. Amsterdam: Elsevier.

Blackett, E. J., Page, A. A., Zalasiewicz, J. A., Williams, M., RickARDS, R. B. \& DAVIES, J. R. 2009. Refined graptolite biostratigraphy for the late Ordovician-early Silurian of central Wales. Lethaia $\mathbf{4 2}$, 83-96.

BRigGS, D. E. G. \& WiLliams, S. H. 1981. The restoration of fossil graptolites. Lethaia 14, 157-64.

CHEN, X. \& Lin Y.-K. 1978. Lower Silurian graptolites from Tongzi, northern Guizhou. Memoirs of Nanjing Institute of Geology and Palaeontology, Academia Sinica 12, 1-75. [In Chinese]

Chen, X., Fan, J.-X., Melchin, M. J. \& Mitchell, C. E. 2005. Hirnantian (Latest Ordovician) graptolites from the Upper Yangtze region, China. Palaeontology 48, 235-80.

Chen, X., Rong, J., Mitchell, C. E., HARPER, D. A. T., FAN, J., ZHAN, R., ZHANG, Y., LI, R. \& WANG, Y. 2000. Late Ordovician to earliest Silurian graptolite and brachiopod biozonation from the Yangtze region, South China, with a global correlation. Geological Magazine 137, 623-50.

Cherns, L. \& WheEley, J. R. 2007. A pre-Hirnantian (Late Ordovician) interval of global cooling - the 'Boda event' reassessed. Palaeogeography, Palaeoclimatology, Palaeoecology 251, 449-60.

CHURKIN, C. \& CARTER, C. 1970. Early Silurian graptolites from southeastern Alaska and their correlation with graptolitic sequences in North America and the Arctic. United States Geological Survey, Professional Paper $T S Q, 1-51$.

DAVIES, K. A. 1929. Notes on the graptolite faunas of the Upper Ordovician and Lower Silurian. Geological Magazine 66, 1-27.

Destombes, J., Holland, H. \& WiLlefert, S. 1985. Lower Palaeozoic rocks of Morocco. In Lower Palaeozoic of North-Western and West-Central Africa. Lower Palaeozoic Rocks of the World, Vol. 4 (ed. C. H. Holland), pp. 91-336. Chichester: John Wiley \& Sons.

Elles, G. L. \& WoOD, E. M. R. 1907. A monograph of British graptolites. Part 6. Monograph of the Palaeontographical Society, London 61, 217-72.

FINNEY, S. C. \& BERRY, W. B. N. 1997. New perspectives on graptolite distributions and their use as indicators of platform margin dynamics. Geology 25, 919-22.

ForTEY, R. A. \& COCKS, L. R. M. 2005. Late Ordovician global warming - the Boda Event. Geology 33, 405-8.

Ghienne, J.-F., Boumendual, K., Paris, F., Videt, B., Racheboeuf, P. \& Ait Salem, H. 2007. The Cambrian-Ordovician succession in the Ougarta Range (western Algeria, North Africa) and interference of the Late Ordovician glaciation on the development of the Lower Palaeozoic transgression on northern Gondwana. Bulletin of Geosciences 82, 183-214. 
Goldman, D, Mitchell, C. E., Melchin, M. J., Fan, J-X. \& WU, S-Y. 2011. Biogeography and mass extinction: extirpation and re-invasion of Normalograptus species (Graptolithina) in the Late Ordovician Palaeo-tropics. Proceedings of the Yorkshire Geology Society 58, 227-46.

GOODARZI, F. \& NORFORD, B. S. 1985. Graptolites as indicators of the temperature histories of rocks. Journal of the Geological Society, London 142, 1089-99.

GrignANI, D., LANZONI, E. \& ELATRASH, H. 1991. Paleozoic and Mesozoic subsurface palynostratigraphy in the Al Kufrah Basin, Libya. In The Geology of Libya, Vol. 4 (eds M. J. Salem, O. S. Hammuda \& B. A. Eliagoubi), pp. 1159-228. Amsterdam: Elsevier.

HowE, M. P. A. 1983. Measurement of thecal spacing in graptolites. Geological Magazine 120, 635-8.

HUANG, Z.-G. 1982. Latest Ordovician and earliest Silurian graptolite assemblages of Xainza district, Xizang (Tibet) and Ordovician-Silurian boundary. In Contribution to the Geology of the Qinghai-Xizang (Tibet) Plateau (ed. Editorial Committee of Ministry of Geology and Mineral Resources), pp. 27-52. Beijing: Geological Publishing House. [In Chinese]

HuTT, J. E. 1974. The Llandovery graptolites of the English Lake District. Monograph of the Palaeontographical Society 128, 1-56.

Koren', T. N. \& Mikhaylova, N. F. 1980. Class Graptolithina. In The Ordovician-Silurian Boundary in Kazakhstan (eds M. K. Appollonov, S. M. Bandaletov \& I. F. Nikitkin), pp. 1-300. Alma-Ata: Nauka Kazakhstan SSR Publishing House. [In Russian]

Koren', T. N. \& MELChIN, M. J. 2000. Lowermost Silurian graptolites from the Kurama Range, eastern Uzbekistan. Journal of Paleontology 74, 1093-113.

Koren', T. N. \& RickARDS, R. B. 2004. An unusually diverse Llandovery (Silurian) Diplograptid fauna from the Southern Urals of Russia and its evolutionary significance. Palaeontology 47, 859-918.

JIN, J. 2003. The Early Silurian brachiopod Eocoelia from the Hudson Bay Basin, Canada. Palaeontology 46, 885-902.

LAPWORTH, C. 1877. On the Graptolites of County Down. Proceedings of the Belfast Naturalists' Field Club Appendix 4, 125-44.

LAPWORTH, H. 1900. The Silurian sequence of Rhayader. Quarterly Journal of the Geological Society of London 56, 67-137.

LEGRAND, P. 1977. Contribution a l'etude des graptolites du Llandoverien inferieur de l'Oued In Djerane (Tassili N'ajjer oriental, Sahara algérien). Bulletin de la Société d'Histoire Naturelle de l'Afrique du Nord 67, 141-96.

LEGRAND, P. 1986. The Silurian graptolites of Oued In Djerane: a study of populations at the Ordovician-Silurian boundary. In Palaeoecology and Biostratigraphy of Graptolites (eds C. P. Hughes \& R. B. Rickards), pp. 1-277. Geological Society of London, Special Publication no. 20.

LEGRAND, P. 1987. Modo de desarrollo del Suborden Diplograptina (Graptolithina) en el Ordovícico Superior y en el Silúrico. Implicaciones taxonómicas. Revista Española de Paleontología 2, 59-64.

LEGRAND, P. 2000. Une région de référence pour la limite Ordovicien-Silurien: l'Oued In Djerane Sahara algérien. Comptes Rendus de l'Académie des sciences Paris, Sciences de la Terre et des planètes 330, 61-66.

LEGRAND, P. 2001. La faune graptolitique de la région d'In Azaoua (Tassili Oua-n-Ahaggar, confines algéronigériens). Annales de la Société Géologique du Nord 8, 137-58.
LEgrand, P. 2003. Paléogéographie du Sahara algérien à l'Ordovicien terminal et au Silurien inférieur. Bulletin de la Société Géologique de France 174, 19-32.

LEGRAND, P. 2009. Faunal specificity, endemism and paleobiography: the post-glacial (Hirnantian-early Rhuddanian) graptolite fauna of the North-African border of Gondwana: a case study. Bulletin de la Société Géologique de France 180, 353-67.

Le Heron, D. P., Armstrong, H. A., Wilson, C., Howard, J. P. \& GINDRE, L. 2010. Glaciation and deglaciation of the Libyan Desert: the Late Ordovician record. Sedimentary Geology 223, 100-25.

LE Heron, D. P. \& CRAIG, J. 2008. First-order reconstructions of a Late Ordovician Saharan Ice Sheet. Journal of the Geological Society, London 165, 19-29.

LE Heron， D. P. \& HowARD，J. P. 2010. Evidence for Late Ordovician glaciation of Al Kufrah Basin, Libya. Journal of African Earth Sciences 58, 354-364.

Le Heron, D. P., Meinhold, G., Page, A. A. \& Whitham, A. In press. Did lingering ice sheets moderate anoxia in the Early Palaeozoic of Libya? Journal of the Geological Society, London. doi:10.1144/jgs2012-108

Le Heron, D. P., Sutcliffe, O. E., Whittington, R. J. \& CRAIG, J. 2005. The origins of glacially related soft sediment deformation structures in Upper Ordovician glaciogenic rocks: implication for ice sheet dynamics. Palaeogeography, Palaeoclimatology, Palaeoecology 218, 75-103.

LI, J.-J. \& YANG, X. C. 1983. In Palaeontological Atlas of East China, Part 1, Early Palaeozoic (ed. Nanjing Institute of Geology and Mineral Resources), pp.1-657. Beijing: Geological Publishing House. [In Chinese]

LOYDELL, D. K. 2007. Graptolites from the Upper Ordovician and Lower Silurian of Jordan. Special Papers in Palaeontology 78, 1-66.

LOYDELL, D. K. 2012a. Graptolite biozone correlation charts. Geological Magazine 149, 124-32.

LOYDELL, D. K. 2012b. Graptolite biostratigraphy of the E1NC174 core, Rhuddanian (lower Llandovery, Silurian), Murzuq Basin (Libya). Bulletin of Geosciences 87, 651-60.

LOYdell, D. K., Butcher, A., FrÝdA, J., LÜNING, S. \& FOwLER, M. 2009. Lower Silurian "Hot Shales" in Jordan: a new depositional model. Journal of Petroleum Geology 32, 261-70.

LÜNING, S., CRAig, J., Fitches, W. R., Mayouf, J., Busrewil, A., El Dieb, M., Gammudi, A., LOYDELl, D. \& MCIlroy, D. 1999. Re-evaluation of the petroleum potential of the Kufra Basin SE Libya, NE Chad: does the source rock barrier fall? Marine and Petroleum Geology 16, 693-718.

LÜning, S., Craig, J., Loydell, D. K., Štorch, P. \& FITCHES, B. 2000. Lower Silurian 'hot shales' in North Africa and Arabia: regional distribution and depositional model. Earth-Science Reviews 49, 121-200.

MANCK, F. 1923. Untersilurische Graptolithenarten der Zone 10, ferner Diversograptus gen. nov., sowie einige neue Arten anderer Gattungen. Die Natur 14, 282-89.

M'CoY, F. 1850. On some new genera and species of Silurian Radiata in the collection of the University of Cambridge. Annals and Magazine of Natural History 6, 270-90.

MelChIN, M. J. 1998. Morphology and phylogeny of some early Silurian 'diplograptid' genera from Cornwallis Island, Arctic Canada. Palaeontology 41, 263-315.

MelChIN, M. J. 2008. Restudy of some Ordovician-Silurian boundary graptolites from Anticosti Island, Canada, and their biostratigraphic significance. Lethaia 41, 155-62.

Melchin, M. J. \& Mitchell, C. E. 1991. Late Ordovician extinction in the Graptoloidea. In Advances in 
Ordovician Geology (eds C. R. Barnes \& S. H. Williams), pp. 143-56. Geological Survey of Canada Paper no. 90-9.

Melchin, M. J., Mitchell, C. E., NACZK-CAmeron, A., FAN, J-X. \& LOXTON, J. 2011. Phylogeny and adaptive radiation of the Neograpta (Graptoloida) during the Hirnantian mass extinction and Silurian recovery. Proceedings of the Yorkshire Geology Society 58, 281-309.

MU, E.-Z. \& LIN, Y.-K. 1984. Graptolites from the Ordovician-Silurian boundary sections of Yichang area, S. Hubei. In Stratigraphy and Palaeontology of Systemic Boundaries in China, Ordovician-Silurian Boundary Vol. 1 (ed. Nanjing Institute of Geology \& Palaeontology, Academia Sinca), pp. 45-73. Hefei: Anhui Science and Technology Publishing House.

MU, E.-Z. \& NI, Y.-N. 1983. Uppermost Ordovician and lower-most Silurian graptolites from Xainza area of Xizang (Tibet) with a discussion on the OrdovicianSilurian boundary. Paleontologia Cathayana 1, 155-79. [In Chinese]

OBut, A. M. \& SobolevskayA, R. F 1967. In Graptolites and Stratigraphy of the Lower Silurian along the Margins of the Kolyma Massif (eds A. M. Obut, R. F. Sobolevskaya \& A. A. Nikolaev), pp. 1-164. Akademiya Nauk SSR, Sibirskoe otdelenie, Institut geologii i geofiziki, Ministerstvo geologii SSSR, Nauchno-issledovatel'sky institut geologii Arktiky. [in Russian]

Page, A. A., Zalasiewicz, J. A., Williams, M. \& POPOV, L. E. 2007. Were transgressive black shales a negative feedback modulating glacioeustacy in the Early Palaeozoic icehouse? In Deep-Time Perspectives on Climate Change: Marrying the Signal from Computer Models and Biological Proxies (eds M. Williams, A. M. Haywood, F. J. Gregory \& D. N. Schmidt), pp. 123-56. The Micropalaeontological Society, Special Publications. London: The Geological Society.

PERner, J. 1895. Études sur les Graptolites de Bohême. IIIième Partie. Monographie des Graptolites de l'Étage $D$. Prague: Raimond Gerhard, $31 \mathrm{pp}$.

RICKARDS, R. B. 1970. The Llandovery (Silurian) graptolites of the Howgill Fells, Northern England. Palaeontographical Society Monographs 123, 1-108.

RICKARDS, R. B. 2002. The graptolitic age of the type Ashgill Series (Ordovician), Cumbria, UK. Proceedings of the Yorkshire Geological Society 54, 1-16.

Rickards, R. B., RigBy, S., Rickards, J. \& Swales, C. 1998. The hydrodynamics of graptolites assessed by laser Doppler anemometry. Palaeontology 41, 737-52.

Seilacher, A., LÜning, S., Martin, M.A., Klitzsch, E., KhOJA, A. \& CRAIG, J. 2002. Ichnostratigraphic correlation of Lower Palaeozoic clastics in the Kufra Basin (SE Libya). Lethaia 32, 257-62.

SOBOLEVSKAYA, R. F. 1974. New Ashgill graptolites in the middle flow basin of the Kolyma River. In Graptolites of the USSR (ed. A. M. Obut), pp. 63-71. Novosibirsk: Nauka, Siberian Branch. [In Russian]

ŠTORCH, P. 1989. Late Ordovician graptolites from the upper part of the Králùv Dvưr Formation of the Prague Basin (Barrandian, Bohemia). Věstník Českého geologického ústavu 64, 173-86.

ŠTORCH, P. \& FEIST, R. 2008. Lowermost Silurian graptolites of Montagne Noire, France. Journal of Paleontology 82, 938-56.

ŠTORCH, P. \& MASSA, D. 2003. Biostratigraphy, correlation, environmental and biogeographic interpretation of the Lower Silurian graptolite faunas of Libya. In The
Geology of Northwest Libya, Vol. 1 (eds M. J. Salem \& K. M. Oun), pp. 237-51. Malta: Gutenberg Press Ltd.

Štorch, P., Mitchell, C. E., FinNey, S. C. \& Melchin, M. J. 2011. Uppermost Ordovician (upper KatianHirnantian) graptolites of north-central Nevada, USA. Bulletin of Geosciences 86, 301-86.

ŠTORCH, P. \& SERPAGLI, E. 1993. Lower Silurian graptolites from southwestern Sardinia. Bollettino della Società Paleontologica Italiana 32, 3-57.

SuN, Y.-Z. 1933. Ordovician and Silurian graptolites from China. Palaeontographica Sinica B14, 1-52. [In Chinese]

Sutcliffe, O. E., Harper, D. A. T., Salem, A. A., WhitTington, R. J. \& CRAIG, J. 2001. The development of an atypical Hirnantia brachiopod Fauna and the onset of glaciation in the late Ordovician of Gondwana. Earth and Environmental Science Transactions of the Royal Society of Edinburgh 92, 1-14.

TÖRNQUIST, S. L. 1897. On the Diplograptidae and Heteroprionidae of the Scanian Rastrites beds. Acta Universitatis Lundensis 33, 1-24.

UNDERWOOD, C. J. 1992. Graptolite preservation and deformation. Palaios 7, 178-86.

Underwood, C. J. \& BotTrell, S. H. 1994. Diagenetic controls on the pyritization of graptolites. Geological Magazine 131, 315-27.

Underwood, C. J., DeynouX, M. \& GHIEnNE, J.-F. 1998. High palaeolatitude (Hodh, Mauritania) recovery of graptolite fauna after the Hirnantian (end Ordovician) extinction event. Palaeogeography, Palaeoclimatology, Palaeoecology 142, 91-105.

WALKeR, L. J., Wilkinson, B. H., IVANY, L. C. 2002. Continental drift and Phanerozoic carbonate accumulation in shallow-shelf and deep-marine settings. Journal of Geology 110, 75-87.

WAERN, B. 1948. The Silurian strata of the Kullatorp Core. In Deep Boring Through Ordovician and Silurian Strata at Kinnekulle, Vestergötland (eds B. Waern, P. Thorslund \& G. Henningsmoen), pp. 433-74. Bulletin of the Geological Institutions of the University of Uppsala no. 32.

WILLIAMS, S. 1982a. The Late Ordovician graptolite fauna of the Anceps Bands at Dob's Linn, southern Scotland. Geologica et Palaeontologica 16, 29-56.

Williams, S. H. 1982b. Upper Ordovician graptolites from the top Lower Hartfell Shale Formation (D. clingani and $P$. linearis zones) near Moffat, southern Scotland. Transactions of the Royal Society of Edinburgh: Earth Sciences 72, 229-55.

ZALASIEWICZ, J. A. 2001. Graptolites as constraints on models of sedimentation across Iapetus: a review. Proceedings of the Geologists' Association 112, 237 51.

Zalasiewicz, J. A., TAYlor, L., Rushton, A. W. A., LOYDELl, D. K., RiCKARDS, R. B. \& Williams, M. 2009. Graptolites in British stratigraphy. Geological Magazine 146, 785-850.

ZALASIEWICZ, J. A. \& TUNNICLIFF, S. P. 1994. Uppermost Ordovician to Lower Silurian graptolite biostratigraphy of the Wye valley, central Wales. Palaeontology 37, 695720.

Zalasiewicz, J., Williams, M., Miller, M., Page, A. \& BLACKETT, E. 2007. Early Silurian (Llandovery) graptolites from central Saudi Arabia: first documented record of Telychian faunas from the Arabian Peninsula. GeoArabia 12, 15-36.

ZiegleR, A. M., Cocks, L. R. M. \& BAMBACH, R. K. 1968. The composition and structure of Lower Silurian marine communities. Lethaia 1, 1-27. 